\title{
Hastane Öncesi Sağlık Hizmetlerine Yönelik Çalışan Özel Ambulans Personellerinin Tükenmişlik Düzeylerine Bağlı İşten Ayrılma Niyeti
}

\author{
Çiğdem Koçyiğit Poyraz ${ }^{1 *}$, Menekşe Kılıçarslan ${ }^{2}$ \\ 1* İstanbul Aydın Üniversitesi, Sağlık Bilimleri Fakültesi, Sağlık Kurumları Yöneticiliği Bölümü, İstanbul, Türkiye,(ORCID: 0000-0002-9453-5940), cigdem- \\ kocyigit@hotmail.com.tr
}

2 İstanbul Aydın Üniversitesi, Sağlık BilimleriFakültesi, Sağlık Yönetimi Bölümü, İstanbul, Türkiye (ORCID:0000-0002-0580-8645), meneksekilicarslan@aydin.edu.tr (Illk Geliş Tarihi Aralık 2020 ve Kabul Tarihi Ocak 2021)

(DOI: $10.31590 /$ ejosat.852202)

ATIF/REFERENCE: Koçyiğit Poyraz, Ç. \& Kılıçarslan, M. (2021). Hastane Öncesi Sağlık Hizmetlerine Yönelik Çalışan Özel Ambulans Personellerinin Tükenmişlik Düzeylerine Bağlı İșten Ayrılma Niyeti. Avrupa Bilim ve Teknoloji Dergisi, (22), 364-373.

\section{Öz}

Tükenmişlik sendromu, stresle mücadele edememe sonucu bireyin enerji ve güç kaybı sonrası duyarsızlaşma duygusal ve ruhsal olarak tükenme durumu olarak ifade edilmektedir. Bu çalışmada özel ambulans personellerinin tükenmişlik düzeylerine bağlı işten ayrılma niyeti etkisini incelenmiştir. Çalışmanın amacı tükenmişlik sendromu, işten ayrılma niyeti değişkenlerinin ve alt boyutlarının birbirleriyle olan ilişkilerini incelemek ve tükenmişlik duygusunun işten ayrılma niyetine etkisini ortaya koymaktır.

Araştırma kısmında; sosyo-demografik(tanıtıcı) bilgiler, Maslach tükenmişlik ölçeği, JP Walsh, ve arkadaşları SJ Ashford, TE Hill tarafından $1985^{\prime}$ te geliştirilen işten ayrılma niyeti ölçeği kullanılmıştır. Veriler SPSS 18.0 istatistik paket programı kullanılarak analiz edilmiştir.

Araştırma ölçekleri ve alt boyutlarının güvenirlik analizi bulguları Cronbach alfa katsayısı ölçüsüyle değerlendirilmiştir. Birbiriyle tutarlı ve aynı özelliğin öğelerini yoklayan maddelerden oluştuğu ve tüm maddelerin tutarlı bir biçimde birlikte çalıştığı istatiksel olarak elde edilmiştir. Araştırma ölçekleri ve alt boyutları güvenilirlik analizi sonucu yüksek güvenirlikli ve oldukça güvenirlikli olarak bulunmuştur.

Analiz sonuçlarının değerlendirilmesinde; Tükenmişlik ölçeği alt boyutlarının ve İşten ayrılma niyeti arasındaki ilişkinin istatistiki olarak anlamlı olduğu ortaya çıkmıştır. Katsayıların student-t istatistiği değerlerine bakıldığında duygusal tükenme boyutundaki ve duyarsızlaşma boyutundaki değişiminin işten ayrılma niyeti değişkeni üzerinde pozitif bir etkiye sahip olduğu, ancak kişisel başarı boyutunun İşten Ayrılma Niyeti değişkeni üzerinde negatif bir etkiye sahip olduğu görülmektedir. Dolayısıyla çalışanların tükenmişlik düzeylerinin işten ayrılma niyetine etkisi olduğu ortaya çıkmıştır.

Anahtar Kelimeler: İșten Ayrılma niyeti, Sağlık Personeli, Tükenmişlik, Tükenmişlik Sendromu.

\section{An Intention of Private Ambulance Staffs Working for Prehospital Health Care to Intention to Leave Work Depending on Burnout Levels}

\begin{abstract}
Burnout syndrome is expressed as the desensitization, emotional and mental exhaustion of the individual after loss of energy and strength as a result of not being able to struggle against stress. In this study, the effect of private ambulance staffs' burnout levels on intention of quitting job was examined. The aim of the study is to examine the relationship between variables of burnout syndrome and intention of intention to leave work and their sub-dimensions and to reveal the effect of feeling burnout on the intention to leave work.
\end{abstract}

\footnotetext{
* Sorumlu Yazar: cigdem-kocyigit@hotmail.com.tr ; Bu çalışma sorumlu yazarın yüksek lisans tezinden türetilmiştir. 
In the research, socio-demographic (introductory) information, Maslach burnout scale, intention to leave work scale developed by JP Walsh, and his friends; SJ Ashford, TE Hill in 1985 were used. The data were analyzed using SPSS 18.0 statistical software.

The reliability analysis of the research scales' findings and their sub-dimensions were evaluated with the Cronbach alpha coefficient measure and it was found that their items are consistend with each other and they are highly reliable.

In the evaluation of the results of the analysis, it was found that the relationship between burnout scale sub-dimensions and the intention to intention to leave work was statistically significant. When the student-t statistic values of the coefficients are analyzed, it can be seen that the change in the emotional exhaustion dimension and the desensetization dimension has a positive effect on the variable of intention to leave work, but the individual success dimension has a negative effect on the variable of intention to leave work. Therefore, it has been revealed that burnout levels of the staffs have an effect on the intention to intention to leave work.

Keywords: Intention to Leave Work, Health Personnel, Burnout, Burnout Syndrome.

\section{Giriş}

Tükenmişlik, bireyin iş hayatını, aile yaşantısını ve sosyal çevresiyle olan ilişkilerini olumsuz olarak etkilemektedir. Stres ve tükenmişlik sadece iş ortamlarında değil hayatın her alanında görülmektedir. Stres zamanla insanlarda hem bireysel hem de örgütsel tükenmişlik yaşanmasında sebep olmaktadır.

İnsanlar hayatlarını devam ettirebilmek için çalışmak zorundadırlar. Zamanlarının büyük bir bölümünü geçirdikleri bu iş ortamlarında yaptıkları işin zorluğuna yoğunluğuna, çeşitliliğine vb durumlara bağlı olarak çeşitli boyutlarda strese maruz kalmaktadırlar.

Çalışan kişinin verimliliği ne kadar sağlıklı olduğuna bağlıdır ve Dünya Sağlık Örgütü (DSÖ) Tüzüğü'nde sağllğın tanımı şu şekilde yapılmıştır: "Yalnızca hastalık veya sakatlığın olmaması durumu değil, fiziksel, sosyal ve ruhsal yönden tam iyilik halidir." Günümüzde giderek yaygınlaşarak bir sorun haline gelen tükenmişlik, meslek hayatında aşırı ve uzun süreli yaşanan olumsuzlukların stres sonucu duygusal, zihinsel ve fiziksel yönden bireyin karşı karşıya kaldığı bitkinlik olarak tanımlanmaktadır. Bireylerde iş ortamlarında yaşadığı bu tükenmişlik hissi aile ve sosyal çevresine de yansımakta kişilerin sağlık durumlarını olumsuz olarak etkilemektedir.

Hayat biçimi hem kişisel hem de işe ait özellikler de tükenmişliğin oluşmasını sağlamıştır. İnsanların çok çalışarak kendilerine zaman ayırmamaları da bu durumun tetikleyicisi olmuştur. Ayrıca çalışanların çalıştıkları kurum ve meslekleri ile ilgili beklentileri tükenmişliğin artması veya azalmasına neden olmuştur. Tükenmişlik hissi çalışanın enerjisinin azalmasına, zihinsel olarak kendini işten soyutlamasına ve böylece mesleki performansının düşmesine ve hatta işten ayrılma davranışı içinde olmasina neden olmuştur.

Son yıllarda iş stresi ve iş yükünün çok fazla olduğu sağlık sektöründe tükenmişlik olgusu çok fazla yaşanmaya başlanmıştır. $\mathrm{Bu}$ durum sağlık çalışanlarından yüksek performans beklenmesi, uzun çalışma sürelerinin olması ve çok fazla iş yükünün olması sonucu ortaya çıkmaktadır. Tükenmişlik düzeyinin artması ile sağlık çalışanlarının tutum ve davranışlarının olumsuz etkilenmeleri kişisel ve örgütsel başarısını da olumsuz etkilemiştir.

Hastane öncesi acil sağlık hizmetleri afet, kaza ya da hastalık sonucunda acil yardıma ihtiyaç duyan hastalara hastane öncesi sağlık çalışanları tarafından değerlendirilmesi, ilk tedavilerinin yapılması ve güvenli bir şekilde hastaneye nakledilmesini kapsamaktadır. Hastane öncesi sağlık hizmetinin(HSH) asıl amacı mortaliteyi ve morbiditeyi azaltmak sistematik ve fizyolojik hasarları minimuma indirmektir. Hastane öncesi sağlık sisteminin başarılı olması bu sistemin tüm halkalarının eksiksiz ve sağlam olmasına bağlıdır. HSH nin en önemli halkası sağlık personelidir ve personelin eksikliği yahut performansındaki düşüklük amacını saptırabilmektedir.

$\mathrm{Bu}$ çalışmada, özel ambulans sektörü içinde tükenmişlik kavramının işten ayrılma davranışlarına etkisinin sektörel bazda değerlendirilmesi yapılmıştır.

\section{Tükenmişlik Sendromu Kavramı}

Tükenmişlik sendromu, 1974 yılında ilk defa Herbert Freudenberger tarafindan tanımlanarak literatürdeki yerini almıştır (Polatc1 ve Özyer, 2015). Tükenmişliğin herkes tarafindan kabul görmüş ortak bir tanımı yoktur. Herbert Freudenberger tarafindan yapılan tanım sağlık çalışanlarının yorgunluk, hayal kırıklı̆̆ 1 gibi nedenlerle işten ayrılmaları sonucu yapılmıştır. Bu tanımlamayla insanların duygusal tükenme, kişisel başarısızlık ve sosyal olarak yaşanan sorunları dile getirilmiştir.

Yaşamalarını devam ettirmek için çalışmak zorunda kalan insanların çalışma hayatı içinde yaşadıkları sorunlarda gün geçtikçe artmaktadır (Maslach, Schaufeli ve Leiter, 2001). Tükenmişlik sendromu çalışma hayatının zorlukları sonucu daha fazla görülmeye başlanmıştır.

Sürgevil Dalkılıç tükenmişliği; insanın ruhen çökmesi ve yavaş yavaş bu durumun ilerleyerek hastalık haline gelerek kurtuluşunun zor bir süreç olduğunu söylemiş̧ir (Sürgevil Dalkılıç, 2014). Bu tanıma göre tükenmişlik sendromu bir histen çok hastalık olarak nitelendirilmiştir.

Tükenmişlik kavramı, sadece bireyleri iş ortamlarında etkileyen bir kavram değildir. Tükenmişliğin etkileri iş hayatı dışında hayatın tamamında görülmektedir. $\mathrm{Bu}$ etkilerin saptanması amacıyla yapılan çalışmalar artış göstermiştir.

Yapılan diğer bir tanıma göre Tükenme, kişilerin içinde bulunduğu olumsuz şartlar nedeniyle devamlı kötümser ve olumsuz düşüncelere kapılarak, hayat enerjisinin bitmesidir (Barutçu ve Serinkan, 2008). Bu durum bireylerin kendilerini kötü hissederek yaşamdan kopmalarını ve yaşanan değişikliklerin bile farklılık oluşturmayacağı duygusu yaşamalarına neden olmuştur (Mete, 2008).

Tükenmişlik sendromu görülen kişilerde bu durum iş hayatında ortaya çıkarak hayatlarının tümünü etkilemiş̧ir. Tükenmişlik, sadece bireyi etkileyen bir süreç olmaktan ziyade örgütü, bireyin ailesini ve sosyal çevresini de olumsuz olarak etkilemektedir (Sağlam Arı ve Çına Bal, 2008). Tükenmişlik sendromu ele alınırken bu durum dikkate alınmalıdır. 
Tükenmişlik sendromunun; duygusal tükenme, duyarsızlaşma, düşük kişisel başarı olmak üzere üç temel boyutu bulunmaktadır. Duygusal tükenme boyutu, kişinin duygusal kaynaklarının zorlanarak tükenmesi ve böylece çalışanların işlerine odaklanmalarının zorlaşarak sorumluluklarını yerine getirmemeleridir. Duyarsızlaşma; yaşanılan baskı sonucu duyarsız, negatif ve tepkili davranmadır. Düşük kişisel başarı boyutu ise kişinin işi ile ilgili başarıların düşmesi ve kendini yetersiz hissetmesidir (Derin ve Demirel, 2012). Tükenmişlik sendromu sonucu oluşan bu boyutların kendisine has özellikleri bulunmaktadir.

Zamanla daha fazla sorun haline gelen tükenmişlik sendromu kavramı, çalışanların ve bireylerin hayatlarını olumsuz etkileyen, bireyin çalışma ortamlarında potansiyelini azaltan ve bu durum sonucu işverenler için ek maliyetlere neden olan bir süreç olmaktadır (Yücel, 2012).

Tükenmişliğe neden olan faktörler; bireysel, örgütsel ve çevresel faktörler sınıflandırılmıştır.

Bireysel faktörler bireylerin biyolojik ve psikolojik özellikleri tükenmişlik düzeyini belirleyen bir unsurdur. Diğer insanlarla ilişkiler, olaylara karşı yaklaşım, kişinin kendini kontrol edebilme yetisi tükenmişlik düzeyini belirleyen unsurlar olmuştur. Tükenmişlik çalışma ortamlarının her alanında ve her meslek grubunda yaşanabilmektedir (Yeğin, 2014).

- Kişilik özellikleri,

- Beklentiler,

- Çevresel etkenler,

- Medeni durum,

- Yaş,

- Cinsiyet,

- Eğitim durumu,

- Strese yatkın olma,

- Diş kontrol odaklı olma,

- Kendine yeterlilikten yoksun olma,

- Beklenti düzeyi şeklindedir.

Örgütsel faktörler çalışanlarda görülen tükenmişlik birtakım örgütsel faktörlerin etkisiyle oluşmaktadır. Tükenmişlik faktörleri örgütün temel özelliklerine göre değişkenlik gösterebilmektedir. Genel olarak tükenmişliğe neden olan örgütsel faktörler şu şekilde açıklanmıştır (Şıklar ve Tunalı, 2012):

- İşin niteliği,

- İş güvenliği noksanlığg1,

- Çalışma saatleri,

- Yönetimin yetersizliği,

- Rol çatışması-rol belirsizliği,

- Ücret, ceza ve ödül yönetiminin başarısız olması,

- Kararlara katılım olanağının olmaması,

- Terfi imkanlarının yetersiz olması
- Adaletsiz davranılarak çalıșanlar arasında çifte standart uygulanmas1.

Tükenmişlik oluşmasına neden olan unsurlardan bir diğeri de çevresel faktörlerdir. Çevresel faktörlerin içinde bireyleri etkileyen en önemli faktör ailesi ve yakın çevresidir (Budak ve Sürgevil, 2005). Kişilerin diğer insanlarla ilişkileri, sorunlara yaklaşımları ve bu sorunları paylaşarak çözüm üretmeye çalışmaları tükenmişliği azaltmada etkili olmaktadır. (Polatcı, Ardıç ve Türkan, 2014). Aile ve yakın çevresinden, yöneticilerinden destek görmeyen kişilerde tükenmişlik daha fazla yaşanabilmektedir.

Çevresel faktörler, birey ve örgüte sağlanan sosyal destek olarak nitelendirilebilmektedir. Bu bakımdan çevresel faktörleri ayrı değerlendirmeden bireysel ve örgütsel faktörler içinde değerlendirmek mümkündür. Fakat çevresel faktörler tükenmişliğe neden olan bireysel ve örgütsel faktörler ile kıyaslandığında içeriğinin daha dar olduğu görülmüştür.

Tükenmişliğin sonuçları kişiden kişiye değişiklik gösterebilmektedir. Fakat tükenmişlik yaşanan bireylerde geçici ve kalıcı birtakım hasarlar oluşmaktadır. Bu durum bireysel olarak başlayıp zamanla sosyal ve aile yaşantısına yansımaktadır. Birey aile hayatında mutsuz, memnuniyetsiz ve ihmal edilmiş hissetmektedir.

Tükenmişlik çalışma hayatı üzerinde de performansın düşmesi, hata yapma eğiliminin artması, izin almadan işe gelmeme, işe geç gelme, işi savsaklama ve mesleki başarıda azalma gibi birçok olumsuzluklara neden olmaktadır. Çalışanlarda dikkat sorunu yaşanarak işteki yaralanma ve iş kazaları artış göstermiştir (Özen ve Mirzeoğlu, 2015: Ardıç ve Polatçı, 2008: Arı ve Bal, 2008).

Tükenmişlik görülen kişilerin yaşam kaliteleri olumsuz etkilenmekte ve birey kendini mutsuz hissetmektedir. Gerginlik, karamsarlık, uykusuzluk, yorgunluk, iştahsızlık ve baş ağrıları, alınganlık, depresyon, kaygı ve özsaygının azalması gibi duygusal ve fiziksel sorunlar meydana gelmektedir (Özen ve Mirzeoğlu, 2015). Tükenmişlik sendromu iş yaşamı, günlük yaşam ve ilişkilerin dengesini bozan bir etkiye sahiptir. Bu etkinin sonuçlarını en aza indirebilmek için içsel ve bedensel olarak belirtilerin farkına geç olmadan varılmalıdır (Sevencan vd., 2011).

Tükenmişliğin her alanda etkisi olduğunu düşünen araştırmacılar içinde Maslach tükenmişliğin en fazla çalışma kapasitesini düşürücü etkisi olduğunu savunmuştur. Duygusal tükenmişlik çalışanlarda duyarsızlaşmaya; duyarsızlaşmada kişisel başarının düşmesine neden olmuştur.

Tükenmişlik öncelikle insanlarla yüz yüze ve yoğun çalışma saatlerine sahip meslek gruplarında daha fazla yaşanmakta iken günümüzde hemen hemen her meslek grubunda karşılaşılan bir sorun haline gelmiştir (Sevencan vd., 2011: Özen ve Mirzeoğlu, 2015: Ardıç ve Polatç1, 2008; Ören ve Türkoğlu, 2006).

Tükenme bireyin iç dünyasında başlayarak işini, ailesini ve sosyal çevresini etkileyerek aile içi sorunlara, psikosomatik hastalıklara ve hatta iş kaybına neden olmaktadır.

Rekabet avantaj1 sağlamak isteyen örgütler bu avantaj1 sağlamak ve örgütlerinin devamını sağlayabilmek için insan gücüne ihtiyaç duymaktadır. İnsan gücünü elde tutabilmek için çalışanların işlerinden doyum sağlamaları ve motivasyonlarının 
yüksek tutulması tükenmişlik sendromu yaşanmasını engelleyecektir.

Örgütlerin sunmuş olduğu çalışma ortamları ve imkanlar tükenmişlik sürecini etkilemektedir (Kutlu, 2016). Örgütler hizmet sunumu ile tükenmişlik yaşayan çalışanlarını hem bireysel hem de örgütsel olarak etkilemektedir.

Stres ve strese bağlı olarak oluşan tükenmişlik çalışanlarda işin niteliği, işteki rol, iş gerilimi, kurum tipi, çalışma şekli, diğer çalışanlarla uyumsuzluk gibi nedenlere bağlı olarak ortaya çıkmakta, zamanla motivasyon kaybı, işe geç gitme, işe bağlılık ve adaptasyon kaybı gibi nedenlerle işten ayrılma niyeti ortaya çıkar (Sağlam Arı ve Çına Bal, 2008).

Çalışma saatleri ve çalışma koşulları tükenmişliğin bireysel ve örgütsel etkileri üzerinde doğrudan ilişkilidir. Ağır çalışma koşulları ve uzun süreli çalışma çalışanlarda tükenmişliğe neden olmaktadır (Barutçu ve Serinkan, 2008). Tükenmişliğe maruz kalan çalışanlar yorgunluk, bitkinlik, uykusuzluk sonucu hizmet kalitesinde düşme, işe odaklanamama ve iş kazaları yaşayabilmektedir.

Tükenmişlik bireysel ve örgütsel performansı olumsuz etkileyen bir durumdur. Örgütler bu durumun etkilerini en aza indirebilmek için birtakım çalışmalar yapmalıdır (Ardıç ve Polatc1, 2008). Tükenmişliğe dair belirti tespit edildiğinde ilerlemesini önleyici tedbirler alınmalıdır.

\section{Sağlık Çalışanlarında Tükenmişlik}

Sağlık çalışanlarının tükenmişliği hakkında birçok araştırma yapılmıştır. GATA Haydarpaşa Hastanesinde çalışan sağlık personellerine dair Kalemoğlu ve Keskin (2002) tarafindan araştırma yürütülmüş bu araştırma ile sağlık kurumlarındaki sağlık çalışanlarının tükenmişlik düzeyleri saptanmaya çalışılmıştır. Yapılan bu çalışmanın sonuçları sağlık çalışanlarının duygusal tükenmişliklerinin çok yüksek olduğunu göstermiştir (\%45,3). Diğer bir tükenmişlik belirtileri duyarsızlık (\%32) ve kişisel başarının azalması (\%28) olarak görülmüştür. Tükenmişlik oranları servislere göre değerlendirildiğinde acil serviste çalışan sağlık personelinin daha fazla tükenmişlik sendromu belirtileri gösterdikleri görülmüştür.

Costa ve Pinto (2017) sağlık çalışanlarında iş stresi ve tükenmişliklerin neden oluştuğu ve bu tükenmişliğin sonuçlarının neler olduğuna dair yapılan araştırmalardan 48 araştırmanın sonuçlarını inceleyerek çalışma yapmışlardır. $\mathrm{Bu}$ araştırma sonuçları gerek doktorlarda gerekse de hemşirelerde uzun çalışma saatleri, aşırı iş yükü, beklentilerin fazla olması, nöbet sayısının fazla olması sonucu yorgunluk, iş yerinde yaşanan iletişim çatışmaları, olumsuz çalışma koşulları nedeniyle oluşan duygusal ve fiziksel yüklemeler ile tükenmişliğin oluştuğunu göstermiştir. Ayrıca kadın sağlık çalışanlarının iş dışında ki ev hayatındaki sorumluluklarının fazla olması erkek çalışanlara nispeten duygusal tükenme oranının daha fazla olmasına sebep olmuştur. Erkek sağlık çalışanlarında ise tükenmişliğe bağlı olarak "duyarsızlık" eğilimi fazla olmaktadır. Yoğun çalışma temposu karşısında her iki cinsiyetteki sağlık çalışanları zamanla işin gereklerini yerine getirecek performansı gösterememekte kendilerini yetersiz hissederek duygusal tükenmişlik yaşayabilmektedirler.

Hemşirelerin çalışma özellikleri, iş ortamı ve tükenmişliklerinin çalışma performanslarına etkisi Bogaert ve arkadaşları (2014) tarafından araştırılmıştır. Bu araştırmanın sonuçları hemşirelerin duygusal ve kişisel başarısının azalmasında duygusal ve fiziksel tükenmişliğinin, iş performansı üzerinde etkili olduğunu göstermiştir. Çalışma süreleri, vardiyalı ve nöbet sistemine dayalı çalışma da hemşirelerin iş performansının düşmesinde etkilidir.

Tükenmişlik yaşayan sağlık çalışanlarının performansları düşerek motivasyon kaybı yaşamaktadırlar. Zamanla işine ve insanlara karşı duyarsızlaşan sağlık çalışanlarının, hizmet sundukları hastalara duyarsız ve tepkisel davranışlar gösterdikleri gözlenmiştir. Hizmet verilenlere karşı ilgisiz davranarak insanların ihtiyaçlarına önem vermeyen tükenmişlik sendromu yaşayan sağlık çalışanları insanları nesne olarak görmektedirler. $\mathrm{Bu}$ durum sağlık personeli ve hasta arasında, kurum arasında sorunlar yaşanmasına neden olmuştur (Costa ve Pinto, 2017).

Tükenmişlik yaşayan sağlık çalışanları çalışma ortamından kaynaklanan birçok faktörden etkilenmektedir. İngiltere'de görev yapan pratisyen hekimler ile Kuzey Amerika'da çalışan meslektaşları arasındaki tükenmişlikleri incelemek amacıyla araştırma yapan Kirwan ve Amstrong (1995) bu çalışması sonucu İngiltere'deki pratisyen doktorlarda daha fazla tükenmişlik gözlemlenmiştir. Tükenmişlik oluşan doktorlarda zamanla duyarsızlaşma başlamaktadır. Doktorların yaşları duyarsızlığı etkilemektedir.

Tükenmişlik her sektörde olduğu gibi sağlık sektöründe de çok önemli bir sorun haline gelmiştir. $\mathrm{Bu}$ süreçte sağlık çalışanlarının tükenmişlik düzeyleri saptanarak verdikleri tepkilerin düzeltilmesine yönelik eğitimler verilmelidir.

\section{Sağlık Çalışanlarıda İşten Ayrılma Niyeti}

İşten ayrılma niyeti; çalışanların davranışsal bir tutum olarak çalıştıkları örgütten ayrılmak istemelerini ifade etmektedir. Diğer bir tanıma göre işten ayrılma niyeti işletmenin devamlılığını tehdit eden işletme içi ve işletme dışı personelin hareketlerinin seviyesi şeklinde yapılmıştır (Vnouckova ve Klupakova, 2013). İşten ayrılma niyeti çalışanların örgütün sağlamış olduğu iş ve çalışma koşullarından memnun olmamaları sonucu ortaya çıkmaktadır.

İşten ayrılma niyeti, düşünme, planlama ve işten ayrılmaya karar verme aşamalarından oluşur. Örgüt içinde çalışanlar bireysel ya da örgüte bağlı sebeplerden ötürü düşünme evresinden karar vermeye ve daha sonra da işten ayrılma eylemine yönelirler. $\mathrm{Bu}$ süreç örgüt açısından maliyetlerin artmasına neden olur. Örgüt için nitelikli insan gücü kaybı, yeni iş gücü elde edilerek bu iş gücünün eğitilmesi yeni masraflara neden olmaktadır. Firmalar potansiyel iş gücünü elde tutabilecek davranış içinde olarak nitelikli insan gücünü işe bağlayacak tedbirler almalıdır (Eren ve Saraçoğlu, 2011).

Diğer sektörlerde yaşandığı gibi sağlık ve hastane sektöründe de çalışanların birtakım şikayetleri işten ayrılma niyetini ortaya çıkarmakta ve bu durumdan kurumsal performans olumsuz olarak etkilenmektedir. İş doyumu sağlanmayan sağlık personelleri işte verimli çalışmayarak hasta bakım kalitesini düşürebilmektedir. Hastane idaresi, çalışanlarının refahını sağlayacak yöntemler geliştirerek iş doyumunu sağlamalı ve işten ayrılma niyetini en aza indirmelidir (Tanner, 2007).

Sağlık çalışanları beklentilerinin kurum tarafindan karşılanmaması durumunda işi bırakma davranışı gösterirler. İşten ayrılma davranışı hem birey hem de kurum tarafından 
olumsuz etkileri bulunmaktadır (Tanner, 2007). Sağlık personellerinin iş doyumu, motivasyon ve kuruma bağlılık düzeyinin düşük olması işten ayrılma niyetinin oluşmasına neden olur. İşten ayrılma niyeti içinde olan kurum çalışanı daha iyi şartlarda iş imkanı bulamadığı taktirde kurumda çalışmaya devam eder. Kurumda çalışmak istemeyen sağlık personeli kuruma faydalı olmamaktadır. Daha az verimle çalışarak hastanenin devir hızını düşürmektedir. Ayrıca bu durum hastalara daha düşük kalitede hizmet verilmesine neden olmaktadır (Park ve Kim, 2009, 20).

Yüksek performansla çalışan sağlık personelinin işten ayrılması diğer çalışan personellerin motivasyonunu ve verimliliğini de etkilemektedir. Boşalan pozisyona yeni personel bulunmasına kadar geçen sürede kurum içinde çalışan diğer personellerin bu boşluğu doldurabilmeleri için daha fazla çalışmaları gerekmektedir. $\mathrm{Bu}$ durum çalışmaya devam eden hekim ve hemşirelerin iş yüklerinin artmasına ve motivasyonlarının düşmesine neden olacaktır (Jones, 2004).

Sağlık personellerinde işten ayrılma davranışı oluşmasını engellemek için bazı tedbirler alınmalı ve işten ayrılma davranışı sonucu oluşan olumsuzluklar giderilmeye çalışılmalıdır. $\mathrm{Bu}$ durum sağlık çalışanını kuruma tekrar kazandırmayı sağlamaktadır. Aksi taktirde işten ayrılmaların artması durumunda kurumun kalitesi ve başarısı düşerek gelirlerinde azalma olması kaçınılmaz olacaktır.

\section{5. İşten Ayrılma Niyeti ve Tükenmişlik Sendromu Arasındaki İlişki}

Tükenmişlik sendromunun dört tane evresi bulunmaktadır. İşten ayrılma niyeti ile tükenmişlik arasında ilişkiyi saptamak için tükenmişlik sendromunun dört evresinden faydalanılmalıdır. $\mathrm{Bu}$ evreler; şevk ve coşku evresi, durağanlaşma evresi, engellenme evresi ve umursamazlık evresidir (Üngüren vd., 2010: 2924).

Memnuniyet düzeyi yüksek olan çalışanların şevk ve coşku evresinde işten ayrılma niyeti ile tükenmişlik sendromu görülmesi mümkün değildir. Durağanlaşma evresinde, duygusal yönden yıpranmış ve yorgun hisseden birey işine karşı olumsuz düşünceler içinde olarak işten ayrılmayı düşünmeye başlar. $\mathrm{Bu}$ durum tükenmişliğin işten ayrılma niyeti arasında oluşan ilişkinin varlığını gösterir. Üçüncü bir evre olan engellenme evresinde kurumdaki olumsuzlukların düzelmeyeceği ve insanların değişmeyeceği inancı oluşur kişi bu sorunlarla başa çıkmaya çalışarak başarısız olduğuna inanır. Yoğun bir engellenmiş duygusu oluşur. Dördüncü evre olan umursamazlık evresi derin bir inançsızlık ve umutsuzluk hissedilen son evredir. $\mathrm{Bu}$ evrede iş yaşamı kişi için sıkıntı ve mutsuzluk veren ve doğrudan işten ayrılma niyeti ve tükenmişlik sendromu ilişkisini gösteren bir alandır. Bu evreler tükenmişlik sendromunun işten ayrılma niyetine etkisini ve hangi aşamalarda oluştuğunu gösteren tükenmişliği anlamayı kolaylaştıran evrelerdir.

\section{Uygulama}

\subsection{Araştırmanın Amacı}

$\mathrm{Bu}$ çalışmanın temel amacını, hastane öncesi sağlık sektörünün önemli temelini oluşturan özel ambulanslarda çalışanların tükenmişlik vakalarının işten ayrılma niyeti üzerinde bir etkisi olup olmadığını, tükenmişlik sendromu değişkenlerinin ve alt boyutlarının birbirleriyle olan ilişkilerini incelemek ve e-ISSN: 2148-2683 tükenmişlik duygusunun işten ayrılma niyetine etkisini ortaya koymaktır.

\subsection{Araştırmanın Problemi}

Özel ambulansta çalışan sağlık personelinin tükenmişlik sendromuna bağlı işten ayrılma niyeti arasında ilişki var mıdır?

\subsection{Araştırmanın Kısıtlıkları}

Araştırma İstanbul Avrupa yakası Büyükçekmece, Silivri ilçelerinde konumlanmış özel ambulanslarda görev alan sağlık personelleridir. Araştırmanın hedef kitlesi özel ambulansta çalışmakta olan doktor, hemşire, paramedik ve acil tıp teknisyenleridir. Araştırmaya ambulans şoförleri, komuta kontrol merkezi (KKM) çalışanları, sekreter temizlik görevlileri ve yöneticiler dahil edilmemiştir.

Araştırma, veri toplamak amacıyla kullanılan anket formu ile kisitlidir.

\section{Yöntem}

Araştırmada yöntem olarak betimsel tarama modeli kullanılmıştır.

\subsection{Veri Toplama Araçları}

$\mathrm{Bu}$ araştırmanın veri toplama aracı üç bölümden oluşan ankettir. Anketin birinci bölümünde yaş, cinsiyet, aylık gelir vb. sosyo-demografik ve çalışma özellikleri bulunan tanıtıcı bilgiler yer almaktadir.

Anketin ikinci bölümünde duygusal tükenme, duyarsızlaşma, kişisel başarı boyutlarını içinde barındıran Maslach Tükenmişlik Ölçeği kullanılmıştır. Ölçek yirmi iki önermeden oluşmaktadır.

Anketin üçüncü ve son bölümünde çalışanların işten ayrılma niyetini ölçmede, JP Walsh, ve arkadaşları SJ Ashford, TE Hill tarafindan 1985 'te geliştirilen ve Lori J. Ducharme, Hannah Knudsen, Paul M. Roman tarafindan 2007 de yayınlanan "Emotional exhaustion and turnover intention in human service occupations: The protective role of coworker support" çalışmasında kullandıkları ölçekten faydalanılmıştır. Ölçek üç önermeden olușmaktadır.

\subsection{Veri Toplama Aracının Uygulanması}

Araştırmanın ağırlıklı bölgesi İstanbul Avrupa yakası Büyükçekmece, Silivri ilçelerinde konumlanmış özel ambulanslarda görev alan sağlık personelleridir. Araştırmada anket formlarının uygulanması gönüllülük esasına dayanmaktadir.

Araştırma dahilinde özel ambulans şirketlerinin katılımları sağlanması amacıyla yöneticileriyle görüşülmüş araştırmanın amacından bahsedilmiş ve anket örneği sunulmuştur. Çoğu şirket olumsuz cevap vermiş ve iştirakleri sağlanabilen şirketlerin toplam 357 sağlık personeli arasından; katılmak istememe, ilgili sağlık personeline ulaşamama düzensiz çalışma saatleri ve belirsiz konumlar gibi olumsuzluklara rağmen 226 kişi ankete cevap vermiştir.

10.09.2019- 12.12.2019 tarihlieri arasında 7 farklı ambulans şirketinden toplam 357 sağlı personeline ulaşılmış fakat çalışanların \%63'ü olan 226 çalışan katılım sağlamıştır. Anketlerdeki eksik cevaplardan dolayı 24 anket elenmiş ve uygun olan 202 anket araştırmaya tabi tutulmuştur. 
Her anketin başında araştırmanın amacı, gizliliği konusunda açıklama ve gerçeği yansıtır şekilde yanıt vermeleri konusunda uyarı bulunmaktadır. Bunlara ek olarak anket dağıtılırken ilgili kişilere nasıl cevap verileceği konusunda sorular ayrıntılı olarak anlatılmıştır.

Anketler çoğaltılarak ilgili şirketlerin komuta kontrol merkezlerine bırakılmış, çeşitli noktalardaki ambulans içinde bekleyen ekiplere nöbet çizelgeleri takip edilerek dağıtılmıştır. Yine ankete katılmayı kabul etmiş kişilerin nöbet takip çizelgeleri takip edilerek anketler toplanmıştır. Katılımın çok olması amacıyla çeşitli aralıklarla hatırlatmalar yapılmıştır.

\subsection{Veri Analizi}

Veriler SPSS 18.0 istatistik paket programı kullanılarak analiz edilmiştir. Araştırma ölçekleri ve alt boyutlarının güvenirlik analizi bulguları Cronbach alfa katsayısı ölçüsüyle değerlendirilmiş birbiriyle tutarlı ve aynı özelliğin öğelerini yoklayan maddelerden oluştuğu, tüm maddelerin o ölçüde birlikte çalıştı̆̆, yüksek güvenirlikli ve oldukça güvenirlikli olarak bulunmuştur.Sosyo-demografik özellikler ve tükenmişlik ölçeği işten ayrılma niyeti ölçeği değişkenleri arasındaki ilişkinin modelini regresyon analizi(doğrusal regrosyon) ile, elde edilen model aracıllğıyla tahminler bulunma ve regresyon modelinin anlamlılığı ölçmek için ise ANOVA testi yapılmıştır. Farklılığın kaynağı olan gruplar ise TUKEY testi ile belirlenmiştir. Regresyon modelinde değişkenlerin katsayılarının (Beta katsayısı) istatistiksel olarak anlamlı olup olmadığı student-t testiyle incelenmiştir.

\section{Bulgular}

Bu bölümde araştırma anketine katılım sağlayan çalışanların sosyo-demografik özellikleri ve tükenmişlik alt boyutları ile işten ayrılma niyeti düzeyleri, tükenmişlik alt boyutlarıyla işten ayrılma niyeti arasındaki ilişki ile ilgili analiz bulgu ve değerlendirmeler yer almaktadır.

Elde edilen bulgulara göre kadın katılımcıların oranı $\% 46.5$ ve erkek katılımcıların oranı \%53.5 olarak gerçekleşmiştir. Katılımcıların cinsiyet dağılımlarında cinsiyet bakımından büyük bir fark olmamakla birlikte erkek katılımcilar çoğunluktadır.

Ankete katılan bireylerin yaş gruplarına göre frekans dağılımlarından elde edilen bulgulara göre en büyük yığıllma $\% 40.6$ ile 25-30 yaş grubunda ve en az yı̆̆ılma da \%9.4 ile 3640 yaş grubunda olduğu gözlemlenmiştir. 40 yaş üstü çalışana rastlanmaması 36-40 yaş arası çalışan sayısının az olması dikkat çekmektedir.

Ankete katılan bireylerin eğitim durumlarına göre frekans dağılımına bakıldığında katılımcıların \%28,2'sinin Lise, \%50'sinin Ön Lisans, \%18.8'inin Lisans ve \%3'ünün Yüksek Lisans eğitimine sahip oldukları gözlemlenmiştir. Ambulanslarda çalışmak üzere yetiştirilen paramediklerin ön lisans mezunu oldukları ve yine özellikle ambulanslarda çalışması için yetiştirilmiş acil tıp teknisyenlerinin lise mezunu oldukları düşünüldüğünde bu öngörülen bir durumdur. $\mathrm{Bu}$ durum ambulansta çalışan personelin büyük çoğunluğunun ön lisans ve lise mezunu olduğu ileri sürülebilir.

Ankete katılanların medeni durumlarına göre frekans dağıllımlarından elde edilen bulgulara göre katılımcıların $\% 15.8$ 'i evlilerden ve \%84.2'si bekarlardan oluşmaktadır. Çalışan sayısının büyük çoğunluğu bekar olması ambulans şirketlerinin çalışma koşullarının evliliğe uygun olup olmadığı konusunda düşündürmektedir.

Ankete katılan bireylerin gelir durumlarına göre frekans dağı̀lımları bulgularına göre; katılımcıların \%39.6'sının $2000 \mathrm{TL}$ ve alt1, \%23.3'ünün $2001 \mathrm{TL}-3.000 \mathrm{TL}, \% 32.2$ 'si $3001 \mathrm{TL}$ $5.000 \mathrm{TL}$ ve $\% 5.0$ 'ının da $5.001 \mathrm{TL}$ ve üzeri aylık gelire sahip oldukları gözlemlenmiştir. Bu Çizelge bize özel ambulansların çalışan maaşları için ayırdığı bütçenin düşük olduğu görülmektedir. Katılımcıları yaş yüzdeleriyle değerlendirirsek; ankete katılanların \%37.1 i 18-24 yaşında, \%40.6 s1 ise $25-30$ yaş arasındadır. Katılımcıların çalışma hayatına katılma süreleri; 0-1 yıl olanların yüzdesi \%28.7 2-3 yıl olanların sayısı \%32dir. $\mathrm{Bu}$ iki veriye göre çalışanların çoğunun deneyimsiz, yeni mezun ve az deneyimli olabileceğini gösteriyor. Sağlik sektöründe günlük nöbet usulü çalışma sistemi de mevcuttur. Tüm bunlar göz önünde tutulduğunda asgari ücretin altında (2019yılı asgari ücret) ya da biraz üstünde olmasının sebebi anlaşılabilir.

Ankete katılan bireylerin çalı̧̧ma sürelerine göre frekans dağılımından elde edilen bulgulara göre; katılımcıların \%28.7'si 0-1 y1l, \%32.7'si 2-3 y1l, 14,9'u 4-5 y1l, 12,4'ü 6-10 y1l ve $\% 11,4$ 'ü 11 yıl ve üzeri çalışma süresine sahip oldukları gözlemlenmiştir.

Ankete katılan bireylerin şu anki kurumlarında çalışma sürelerine göre frekans dağılımı; katılımcıların \%60,4'ü 0-1 yıldır, \%34,7'si 2-3 yıldır ve \%5,0'1 4-5 yıldır şu anki kurumunda çalışmaktadır. Bu veriye göre katılımcıların \%60.4 ile çoğunluğunun 0-1 yıl arasında çalıştığını gösteriyor. 4-5 yıl çalışanlar katılımcıların \%5 ini oluşturuyor. $\mathrm{Bu}$ durum katılımcıların kurum bağlılığının düşük olduğunu işten ayrılmaların yüksek olduğunu düşündürmektedir.

Ankete katılan bireylerin haftalık çalışma saatlerine göre frekans dağılımından elde edilen bulgulara göre; katılımcıların haftalık olarak \%32.2'si 51-60 saat, \%50.0'1 61-70 saat ve $\% 17.8$ 'i 71 saat ve üzeri çalışmakta oldukları gözlemlenmiştir. 4857 sayılı iş kanunun 63 . Maddesine göre fazla mesai süreleri hariç haftalık standart çalışma süresi 45 saattir. Katılımcıların çalışma saatlerinin standart çalışma süresine göre fazla olması kişilerin iş yerinde fazla vakit geçirdiğini gösteriyor.

Maslach Tükenmişlik Ölçeği, Duygusal Tükenme boyutu maddelerinin frekans dağılımı ve açıklayıcı istatistiklerine göre yüzdelik dilimler incelendiğinde, Maslach tükenmişlik sendromu "01", "02", " $03 "$, " 08 " ve " 20 " maddelerinde cevapların çoğunun "Hiç Katılmıyorum" ve "Katılmıyorum" seçeneklerinde yoğunlaştığı görülmektedir. " 06 " ve "16" maddelerinde ise cevapların "Kararsizım" ve "Kat1lyorum" seçeneklerinde yoğunlaştığı görülmektedir. "13" ve "14" maddelerinde cevapların "Katıllyorum" ve "Tamamen Katılıyorum" seçeneklerinde yoğunlaşması oldukça dikkat çekicidir. Ortalamalar incelendiğinde en düşük ortalamanın " 20 " maddesinde ve en yüksek ortalamanın "14" maddesinde olduğu görülmektedir.

Maslach Tükenmişlik Ölçeği, Duyarsızlaşma boyutu maddelerinin frekans dağılımı ve açıklayıcı istatistiklerine göre yüzdelik dilimler incelendiğinde, Maslach tükenmişlik sendromu " 05 ", " $10 "$ ve " 15 " maddelerinde cevapların çoğunun "Hiç Katılmıyorum" ve "Katılmıyorum" seçeneklerinde yoğunlaştığı görülmektedir. "11" maddesinde cevapların "Katılmıyorum" ve "Kararsızım" seçeneklerinde yoğunlaştığ görülmektedir. "22" maddesinde ise cevapların "Katıliyorum" ve "Tamamen 
Katılıyorum" seçeneklerinde yoğunlaştığı görülmektedir. Ortalamalar incelendiğinde en düşük ortalamanın " 15 " maddesinde ve en yüksek ortalamanın " 22 " maddesinde olduğu görülmektedir.

Maslach Tükenmişlik Ölçeği, Kişisel Başarı boyutu maddelerinin frekans dağglımı ve açıklayıcı istatistiklerine göre yüzdelik dilimler incelendiğinde, Maslach tükenmişlik sendromu "04", "07" ve "12" maddelerinde cevapların "Kat1liyorum" ve "Tamamen Katılıyorum" seçeneklerinde yoğunlaştığı görülmektedir. "09" maddesinde cevapların "Hiç Katılmıyorum" ve "Kararsızım" seçeneklerinde yoğunlaşması dikkat çekicidir. "17", "18", "19" ve " $21 "$ maddelerinde ise cevapların "Kararsızım" ve "Katılıyorum” seçeneklerinde yoğunlaştı̆̆ görülmektedir. Ortalamalar incelendiğinde en düşük ortalamanın "09” maddesinde ve en yüksek ortalamanın "07” maddesinde olduğu görülmektedir.

Maslach tükenmişlik ölçeği, işten ayrılma niyeti boyutu maddelerinin frekans dağılımı ve açıklayıcı istatistiklerine göre yüzdelik dilimler incelendiğinde, işten ayrılma niyeti " 01 " maddesinde cevapların "Kesinlikle Katıliyorum" ve
"Kararsızım" seçeneklerinde yoğunlaştı̆̆ı; "02" maddesinde cevapların "Kesinlikle Katıliyorum" ve "Kesinlikle Katılmıyorum" seçeneklerinde yoğunlaştığı ve "03" maddesinde cevapların "Kesinlikle Katıliyorum" ve "Katılmıyorum" seçeneklerinde yoğunlaştığı görülmektedir. Ortalamalar incelendiğinde en düşük ortalamanın " 03 " maddesinde ve en yüksek ortalamanın " 01 ” maddesinde olduğu görülmektedir.

Duygusal Tükenme, Duyarsızlaşma, Kişisel Başarı ve İşten Ayrılma Niyeti boyutlarının Cinsiyet değişkeni bakımından farklılık olup olmadığı t testi ile incelenmiştir. Elde edilen bulgulara göre ölçeklerin ve alt boyutlarının hiç birisinde cinsiyet değişkeni bakımından istatistiksel olarak anlamlı fark bulunamamıştır.

Duygusal Tükenme, Duyarsızlaşma, Kişisel Başarı ve İşten Ayrılma Niyeti boyutlarının Yaş Grupları değişkeni bakımından farklılık olup olmadığı ANOVA testi ile incelenmiştir elde edilen bulgulara göre boyutların dördünde de yaş grupları değişkeni bakımından istatistiksel olarak anlamlı fark bulunmuştur.

Çizelge 1. Duygusal Tükenme, Duyarsızlaşma, Kişisel Başarı ve Işsten Ayrılma Niyeti boyutlarının Eğitim değişkeni bakımından incelenmesi

\begin{tabular}{|c|c|c|c|c|c|c|c|}
\hline & Eğitim & $\mathrm{N}$ & Ortalama & Standart Sapma & $\mathrm{F}$ & $\mathrm{P}$ & Farklılığın Kaynağı \\
\hline \multirow{4}{*}{ Duygusal Tükenme } & Lise & 57 & 23,21 & 9,755 & 7,759 & 0,001 & Lisans ile Lise \\
\hline & Ön lisans & 101 & 25,46 & 9,486 & & & Lisans ile Ön lisans \\
\hline & Lisans & 38 & 30,58 & 6,079 & & & \\
\hline & Toplam & 196 & 25,80 & 9,325 & & & \\
\hline \multirow[t]{4}{*}{ Duyarsızlaşma } & Lise & 57 & 11,51 & 4,247 & 6,573 & 0,002 & Lisans ile Lise \\
\hline & Ön lisans & 101 & 12,20 & 3,878 & & & Lisans ile Ön lisans \\
\hline & Lisans & 38 & 14,39 & 3,405 & & & \\
\hline & Toplam & 196 & 12,42 & 4,015 & & & \\
\hline \multirow[t]{4}{*}{ Kişisel Başarı } & Lise & 57 & 26,67 & 5,403 & 0,120 & 0,887 & \\
\hline & Ön lisans & 101 & 26,79 & 4,940 & & & \\
\hline & Lisans & 38 & 26,32 & 5,121 & & & \\
\hline & Toplam & 196 & 26,66 & 5,090 & & & \\
\hline \multirow[t]{4}{*}{ İşten Ayrılma Niyeti } & Lise & 57 & 3,08 & 1,329 & 4,266 & 0,015 & Lisans ile Lise \\
\hline & Ön lisans & 101 & 3,18 & 1,247 & & & Lisans ile Ön lisans \\
\hline & Lisans & 38 & 3,78 & 0,972 & & & \\
\hline & Toplam & 196 & 3,27 & 1,245 & & & \\
\hline
\end{tabular}

Duygusal Tükenme, Duyarsızlaşma, Kişisel Başarı ve İşten Ayrılma Niyeti boyutlarının Eğitim değişkeni bakımından farklılık olup olmadığı ANOVA testi ile incelenerek elde edilen bulgular Çizelge 1'de verilmiştir. Elde edilen bulgulara göre "kişisel başarı" boyutu hariç diğer boyutlarda Eğitim değişkeni bakımından istatistiksel olarak anlamlı fark bulunmuştur.
Farklı1ığın kaynağı olan gruplar TUKEY testiyle belirlenerek ilgili boyutun karşısında yazılmıştır.

Duygusal Tükenme, Duyarsızlaşma, Kişisel Başarı ve İşten Ayrılma Niyeti boyutlarında Medeni Durum değişkeni bakımından farklılık olup olmadığı $t$ testi ile incelenmiştir. Elde edilen bulgulara göre ölçeklerin ve alt boyutlarının hiç birisinde medeni durum değişkeni bakımından istatistiksel olarak anlamlı fark bulunamamıştır. 
Çizelge 2. Duygusal Tükenme, Duyarsızlaşma, Kişisel Başarı ve Işsten Ayrılma Niyeti boyutlarının Gelir Durumu değişkeni bakımindan incelenmesi

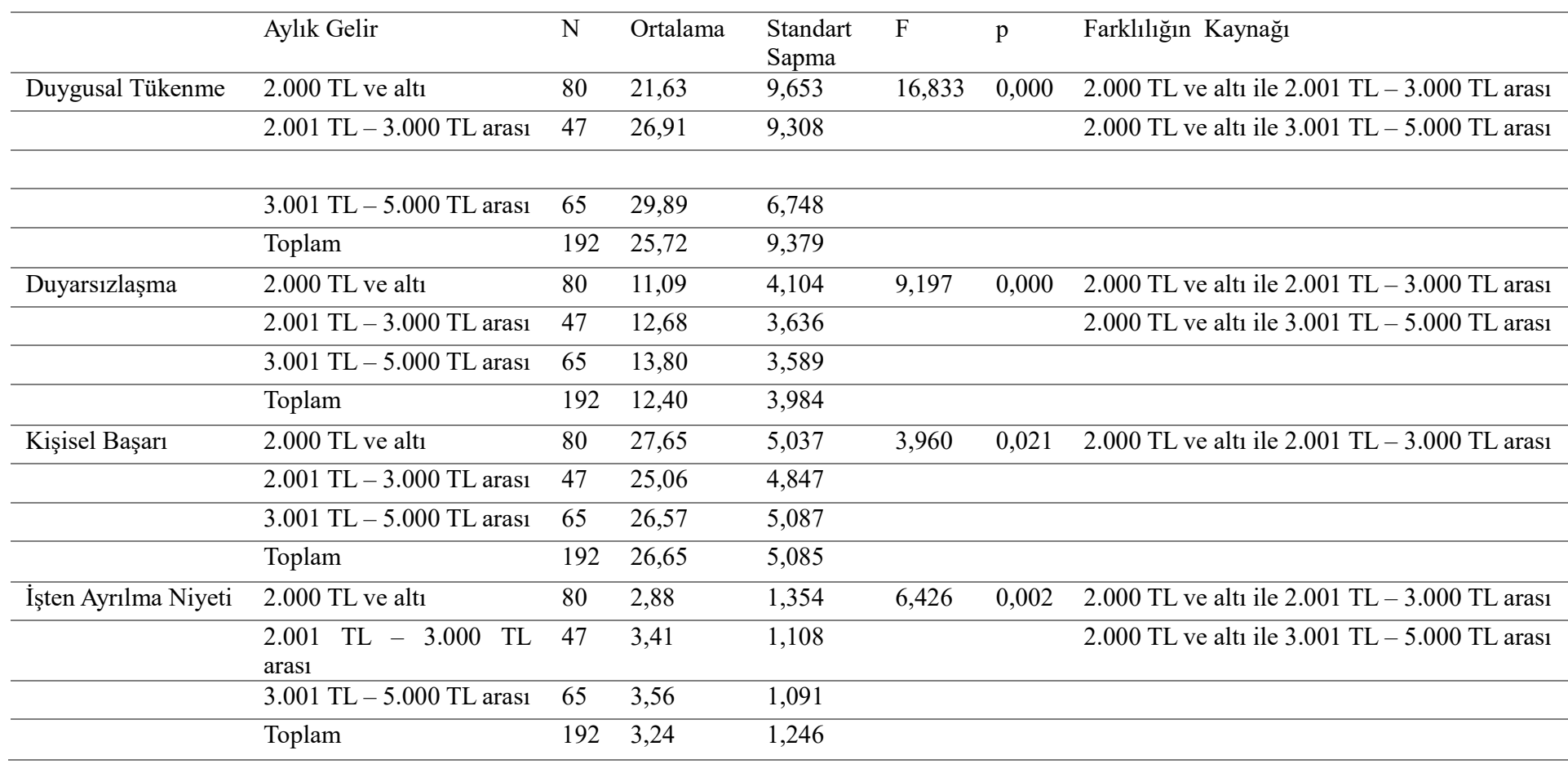

Duygusal tükenme, duyarsızlaşma, kişisel başarı ve işten ayrılma niyeti boyutlarının gelir durumu değişkeni bakımından farklılık olup olmadığı ANOVA testi ile incelenerek elde edilen bulgular Çizelge 2'de verilmiştir. Elde edilen bulgulara göre boyutların dördünde de gelir durumu değişkeni bakımından istatistiksel olarak anlamlı fark bulunmuştur. Farklılığın kaynağı olan gruplar TUKEY testiyle belirlenerek ilgili boyutun karşısında yazılmıştır.

Duygusal Tükenme, Duyarsızlaşma, Kişisel Başarı ve İşten Ayrılma Niyeti boyutlarının Çalışma Süresi değişkeni bakımından farklılık olup olmadı̆̆ elde edilen bulgulara göre "kişisel başarı" boyutu hariç diğer boyutlarda çalışma süresi değişkeni bakımından istatistiksel olarak anlamlı fark bulunmuştur.
Duygusal Tükenme, Duyarsızlaşma, Kişisel Başarı ve İşten Ayrılma Niyeti boyutlarında Kurumda Çalışma Süresi değişkeni bakımından farklılık olup olmadığı student-t testi ile incelenmiştir. Elde edilen bulgulara göre, "duygusal tükenme" ve "duyarsılaş̧ma" boyutlarında istatiksel olarak anlamlı fark bulunmuştur. Ortalamalar incelendiğinde her iki boyutta da kurumda çalışma süreleri 2-5 yıl arası olanların ortalamalarının yüksek olduğu görülmektedir.

Duygusal Tükenme, Duyarsızlaşma, Kişisel Başarı ve İşten Ayrılma Niyeti boyutlarının Çalışma Saati değişkeni bakımından farklılık olup olmadığı ANOVA testi ile incelenmiştir. Elde edilen bulgulara göre "kişisel başarı" boyutunda Çalışma Saati değişkeni bakımından istatistiksel olarak anlamlı fark bulunmuştur.

Çizelge 3. Maslach Tükenmişlik Ölçeği boyutlarının İşten Ayrılma Niyeti boyutu üzerindeki doğrusal regresyon modeli bulguları

\begin{tabular}{lllll}
\hline & Regresyon Katsayıları & Standart Regresyon Katsayıları & $\mathrm{t}$ & $\mathrm{p}$ \\
Sabit & 1,851 & & 3,900 & 0,000 \\
Duygusal Tükenme & 0,069 & 0,514 & 7,029 & 0,000 \\
Duyarsızlaşma & 0,051 & 0,164 & 2,173 & 0,031 \\
Kişisel Başarı & $-0,038$ & $-0,152$ & $-2,820$ & 0,005 \\
R & R kare & Düzeltilmiş R kare & $\mathbf{F}$ & $\mathbf{p}$ \\
$\mathbf{7 0 0}^{\mathbf{a}}$ & 0,489 & 0,482 & 63,259 &, $000^{\text {a }}$ \\
\hline
\end{tabular}

İşten Ayrılma Niyeti boyutu ile Maslach Tükenmişlik Ölçeği boyutları arasındaki doğrusal regresyon modelinin anlamlılığı ANOVA testi ile incelenmiştir. ANOVA testine göre model istatistiksel olarak anlamlı bulunmuş̧ur. Buna göre İşten Ayrılma Niyeti ile Maslach Tükenmişlik Ölçeği boyutları arasındaki ilişki doğrusal regresyon modeliyle incelenebilir. Ayrıca model için düzeltilmiş R-kare katsayısı 0,482 olarak hesaplanmıştır $\mathrm{Bu}$ değer, İşten Ayrılma Niyeti boyutundaki değişkenliğin \%48,2'sinin doğrusal regresyon modeli aracılığıyla Maslach Tükenmişlik Öllçeği boyutları tarafından açıklandığını göstermektedir.

Yeni regresyon modelinin katsayılarının tahmini incelendiğinde, bağımsız değişken olarak alınan üç boyutun da katsayıları t testine göre anlamlı bulunmuştur. Elde edilen modele göre boyutların üçünün de İşten Ayrılma Niyeti boyutu 
üzerinde pozitif etkisi vardır. Buna göre İşten Ayrılma Niyeti Boyutu Y, duygusal tükenme X1, duyarsızlaşma X2 ve kişisel başarı X3 ile gösterilirse doğrusal regresyon modeli

\section{$Y=1,851+0,069 * X 1+0,051 * X 2+-0,038 * X 3$}

olarak elde edilir. Ayrıca standart katsayılara göre, duygusal tükenme boyutundaki 1 birim artış İşten Ayrılma Niyeti değişkeninde 0,514 birim artışa, duyarsızlaşma boyutundaki 1 birim artış İşten Ayrılma Niyeti değişkeninde 0,164 birim artışa ve kişisel başarı boyutundaki 1 birim artış İşten Ayrılma Niyeti değişkeninde 0,152 birim azalmaya neden olması beklenmektedir. Katsayıların student-t istatistiği değerlerine bakıldığında duygusal tükenme boyutundaki ve duyarsızlaşma boyutundaki değişiminin İşten Ayrılma Niyeti değişkeni üzerinde pozitif bir etkiye sahip olduğu, ancak kişisel başarı boyutunun İşten Ayrılma Niyeti değişkeni üzerinde negatif bir etkiye sahip olduğu görülmektedir.

\section{Tartışma}

Her kesimden insan zaman ve yer fark etmeksizin acil tedavi gerektiren bir hastalık ve vaka ile karşı karşıya kalabilir. Yılın her günü 24 saat ihtiyaç duyulan acil sağlık hizmetinin

temelini insan gücü olușturmaktadır. Hastane öncesi acil sağlık hizmetlerini hastanede tedavi edilme sürecine kadarki aşamada, alanlarında yetkin olan personellerce yapılması hasta ve yaralıların hayatını kurtarmak ve sakat kalmaları önlemek açısından oldukça önem arz etmektedir. Çalışanların yaptıkları işten memnun olmaları hayati bir durum gerektiren müdahalelerde daha başarılı olmalarını sağlayacaktır. Aksine işten memnun olunmaması isteksiz olunması ruhsal olarak tam bir iyilik halinde olunmaması ise ciddi sorunlar oluşturabilecek yanlış uygulamalar ve başarısız müdahalelere yol açabilmektedir. Yaşam ile ölüm arasındaki mücadeleyi veren sağlık personelinin uygun koşullar altında çalışmasını

sağlamak gerekmektedir. $\mathrm{Bu}$ durum hayati önem taşıyan aşamadaki verile sağlık hizmetinde başarıyı arttıracaktır.

Sağlık sektörü çalışanları sağlık hizmet alanlar ile birebir iliş̧ki içindedirler. Ambulanslarda görev alan personel, hastaların hastaneye teslim süresi boyunca hastalarla yakından etkileşim içindedirler. bu süreçte hizmeti alan kişiler kendi sağlığıyla ilgilenen kişinin girişimlerinden olumlu ya da olumsuz bir şekilde etkilemektedir. Hastaya müdahale esnasında girişimde bulunan personelin ruhsal zihinsel ve fiziksel olarak sağliklı olması memnuniyet açısından büyük önem taşır.

Özel ambulanslar sosyal güvenlik kurulları tarafindan desteklenmemektedir. Kişi sağlık ödemelerini tamamen kendi cebinden karşılamaktadır bu durumda müssteri memnuniyeti daha bir önem kazanmaktadır. Müşteri memnuniyeti için doğrudan hizmet veren personelin memnuniyeti, işinde yetkin olması ve kurum kültürünü benimsemesi çok büyük bir öneme sahiptir.

Doğrudan hizmet veren işletmenin kar ve devamlllığ kalite, kalite için başarıllı, ruh sağlı̆̆ memnun personellere ihtiyaç vardır.

Araştırmanın veri analizlerine bakacak olursak; katılımcıların \%60,4'ü şuan çalışmakta oldukları şirkette 0-1 yıldır, \%34,7'si 2-3 yıldır çalışmaktadır. Bu durum bu sektörde personel sirkülasyonunun sik olduğunu göstermektedir.

Katılımcıların haftalık olarak \%32.2'si 51-60 saat, \%50.0'1 61-70 saat ve \%17.8'i 71 saat ve üzeri çalışmakta oldukları e-ISSN: $2148-2683$ gözlemlenmiştir. Duygusal Tükenme, Duyarsızlaşma, Kişisel Başarı ve İşten Ayrılma Niyeti boyutlarının Çalışma Saati değişkeni bakımından farklılık olup olmadığı ANOVA testi ile incelenmiştir. Elde edilen bulgulara göre "kişisel başarı" boyutunda Çalışma Saati değişkeni bakımından istatistiksel olarak anlamlı fark bulunmuştur.

Duygusal Tükenme, Duyarsızlaşma, Kişisel Başarı ve İşten Ayrılma Niyeti boyutlarının Gelir Durumu değişkeni bakımından farklılık olup olmadığı ANOVA testi ile incelenmiştir. Elde edilen bulgulara göre boyutların dördünde de gelir durumu değişkeni bakımından istatistiksel olarak anlamlı fark bulunmuştur.

Uzun çalışma saatlerinde mücadele veren çalışanların \%39.6'sinın 2000 TL ve alt1, \%23.3'ünün 2001 TL - 3.000 TL, $\% 32.2$ 'si $3001 \mathrm{TL}-5.000 \mathrm{TL}$ ve $\% 5.0$ ' $1 \mathrm{n}$ n da $5.001 \mathrm{TL}$ ve üzeri aylık gelire sahip oldukları gözlemlenmiştir. Katılımcıların büyük bir bölümüne ayırılan maaş bütçesinin 2019 yılı asgari ücreti göz önüne alınırsa, asgari ücret altında ya da bir miktar üstünde olduğu görülüyor.

Çalışanlara ayırılan maaş bütçesinin artırılması, çalışma saatlerinin 4857 sayılı iş kanunun 63. maddesine göre tekrar düzenlenmesi personelde ruhsal olarak iyileşme sağlayabilir ve daha iyi koşulları olan daha fazla ücret kazanılabilecek farklı bir şirket arayışının, tatminsizliğin başarısızlığın önüne geçilebilir. Böylece yetkin personelin, iş gücü kaybının önlenmesi işletme kalitesinin ona oranla müşteri memnuniyetinin artması beklenir.

\section{Sonuç}

Yapılan araştırmanın sonucuna göre; tükenmişlik ölçeğinin boyutlarından duygusal tükenme ile duyarsızlaşma boyutlarında istatistiksel olarak anlamlı fark bulunmuştur, işten ayrılma niyeti boyutu üzerinde pozitif etkisi vardır. Kişisel başarı boyutunda ise çalışma saati değişkeni bakımındanbir etkisi olduğu görülmüş̧ür. Katılımciların haftalık olarak \%32.2'si 51-60 saat, \%50.0'1 6170 saat ve \%17.8'i 71 saat ve üzeri çalışmakta oldukları gözlemlenmiştir. Maslach Tükenmişlik Ölçeği, Duygusal Tükenme boyutu maddelerinin frekans dağılımı ve açıklayıcı istatistikleri incelendiğinde, Maslach tükenmişlik sendromu "01", "02", "03", "08" ve " $20 "$ maddelerinde cevapların çoğunun "Hiç Katılmıyorum" ve "Katılmıyorum" seçeneklerinde yoğunlaştığı görülmektedir. " 06 " ve " 16 " maddelerinde ise cevapların "Kararsizım" ve "Katıliyorum" seçeneklerinde yoğunlaştığı görülmektedir. "13" ve "14" maddelerinde cevapların "Katıllyorum" ve "Tamamen Katılıyorum" seçeneklerinde yoğunlaşması oldukça dikkat çekicidir. Ortalamalar incelendiğinde en düşük ortalamanın " 20 " maddesinde ve en yüksek ortalamanın " 14 " maddesinde olduğu görülmektedir. 14. Madde işimde çok fazla çalıştı̆̆ımı hissediyorum maddesidir. 4857 sayll iş kanunun 63. Maddesine göre fazla mesai süreleri hariç haftalık standart çalışma süresi 45 saattir. Katılımcıların çalışma saatlerinin standart çalışma süresine göre fazla olması kişilerin iş yerinde fazla vakit geçirdiğini gösteriyor. Bu durum duygusal tükenme yönünden isten ayrılma niyetinde çalışma saatinin etkisini desteklemektedir.

Duygusal tükenme boyutundaki 1 birim artış işten ayrılma niyeti değişkeninde 0,514 birim artışa, duyarsızlaşma boyutundaki 1 birim artış işten ayrılma niyeti değişkeninde 0,164 birim artışa ve kişisel başarı boyutundaki 1 birim artış işten ayrılma niyeti değişkeninde 0,152 birim azalmaya neden 
olması beklenmektedir. Katsayıların Çizelge 3' deki student-t istatistiği değerlerine bakıldığında duygusal tükenme boyutundaki ve duyarsızlaşma boyutundaki değişiminin işten ayrılma niyeti değişkeni üzerinde pozitif bir etkiye sahip olduğu ancak kişisel başarı boyutunun işten ayrılma niyeti değişkeni üzerinde negatif bir etkiye sahip olduğu görülmektedir.

Katılımcıların \%60,4'ü şuan çalışmakta oldukları şirkette 01 yıldır, \%34,7'si 2-3 yıldır çalışmaktadır. Bu durum sektörde personel sirkülasyonunun sık olduğunu göstermektedir.

Demografik değiş̧kenler ile tükenmişlik puanlarında ve işten ayrılma niyeti arasında anlamlı bir ilişki bulunmamıştır fakat katılımcıların \%84.2 sinin bekar olması dikkat çekmektedir.

\section{Teşekkür}

Öncelikle yüksek lisansa başladığım günden bugüne dek her konuda yardımlarını eksik etmeyen bilgi ve tecrübeleriyle araştırmama 1 şık tutan sevgili Dr. Öğr. Üyesi MENEKŞE KILIÇARSLAN'a, İngilizce çevirilerde bana destek olan Psikolog Emine HAFIZOĞLU'na teşekkür ederim. Yaptığım araştırmaya katılım sağlayan sağlık çalışanlarına ve araştırma yapmam için gerekleri izinleri veren özel ambulans şirketlerine, maddi manevi her zaman yanımda olan anne ve babama, sevgili eşim Mert POYRAZ'a teşekkür ederim.

\section{Kaynakça}

Ardıç, K. ve Polatcı, S. (2008). Tükenmişlik sendromu akademisyenler üzerinde bir uygulama, Gazi Üniversitesi İktisadi ve İdari Bilimler Fakültesi Dergisi, 10(2): 69-73.

Arı, G.S. ve Bal, E.Ç. (2008). Tükenmişlik Kavramı: Birey ve Örgütler Açısından önemi. Yönetim ve Ekonomi Dergisi, 15(1): 132.

Barutçu, E. ve Serinkan, C. (2008). Günümüzün Önemli Sorunlarından Biri Olarak Tükenmişlik Sendromu ve Denizli'de Yapılan Bir Araştırma, Ege Akademik Bakış Dergisi, 8(2): 541.

Bogaert, P. V. ve Others. (2014). Nursing unit teams matter: Impact of unit-level nurse practice environment, nurse work characteristics, and burnout on nurse reported job outcomes, and quality of care, International Journal of Nursing Studies, 51(8): 1123.

Budak, G. ve Sürgevil, O. (2005). Tükenmişlik ve Tükenmişliği Etkileyen Örgütsel Faktörlerin Analizine İlişkin Akademik Personel Üzerinde Bir Uygulama. Dokuz Eylül Üniversitesi İktisadi ve İdari Bilimler Fakültesi Dergisi, 20(2): 97.

Costa, B.R.C. ve Pinto, I. (2017). Cristina Jornalo Freire. Stress, Burnout and Coping in Health Professionals: A Literature Review. Journal of Psychology and Brain Studis, 1(1): 1-8.

Derin, N. ve Demirel, E.T. (2012). Tükenmişlik Sendromunun Örgütsel Bağlılığı Zayıflatıcı Etkilerinin Malatya Merkezde Görev Yapan Hemşireler Üzerinde İncelenmesi. Süleyman Demirel Üniversitesi İktisadi ve İdari Bilimler Fakültesi Dergisi, 17(2): 512.

Eren, A. ve Saraçoğlu, B. (2011). Gönüllü İşten Ayrılmalar Üzerine Ekonometrik Bir Yaklaşım, Dokuz Eylül Üniversitesi İktisadi ve İdari Bilimler Fakültesi Dergisi, 26(1): 2 .

Jones, C.B. (2004). The Costs of Nurse Turnover: Part 1: An Economic Perspective, Journal of Nursing Administration, 34(12): 562.
Kalemoğlu, M. ve Keskin, Ö. (2002). GATA Haydarpaşa Eğitim Hastanesi Acil servis Çalışanlarındaki Stres Faktörleri ve Tükenmişlik. Ulus Travma Dergisi, 216.

Kirwan, M. ve Amstrong, D. (1995). Investigation of Burnout in a Sample of British General Practitioners. British Journal of General Practice, (45): 259.

Kutlu, L. (2016). Tükenmişlik ve Başa Çıkma Yöntemleri, Çevrimdışı, Alındığ 1 tarih: 15.03.2019, adres: http://www.cayd.org.tr/tr/images/UserFiles/Documents/Gall ery/Tukenmislik_Basa_Cikma_Yontemleri.pdf

Maslach, C., Schaufeli, W.B. ve Leiter, M.P. (2001). Job Burnout, Annual Reviews Pyschology, 52: 398.

Mete, H. (2008). Kronik Hastalık ve Depresyon, Klinik Psikiyatri, 11: 3-4.

Ören, N. ve Türkoğlu, H. (2006). Öğretmen Adaylarında Tükenmişlik. Muğla Üniversitesi Sosyal Bilimler Enstitüsü Dergisi, 16.

Özen, G. ve Mirzeoğlu, N. (2006). Bir Spor Örgütünde Çalışan Spor Uzmanlarının Tükenmişlik ve Örgütsel Bağlılıklarının İncelenmesi, Spor Yönetimi ve Bilgi Teknolojileri Dergisi, 1(2): 12-13

Park, J.S. ve Kim, T.H. (2009). Do Types of Orgnaziational Culture Matter in Nurse Job Satisfaction And Turnover Intention?, Leadership in Health Services, 22(1): 20.

Polatcı, S., Ardıç, K. ve Türkan, G. (2014). Bağlılık Boyutlarının Tükenmişlik Boyutları Üzerindeki Etkisinin İncelenmesi, Yönetim ve Ekonomi Dergisi, 21(2): 284.

Polatc1, S. ve Özyer, K. (2015). Rol Stresörlerinin Tükenmişlik Üzerindeki Etkilerine Yönelik Bir Araştırma, The Journal of Academic Social Science Studies, 33: 31.

Sağlam Arı, G. ve Çına Bal, E. (2008). Tükenmişlik Kavramı: Birey ve Örgütler Açısından Önemi. Yönetim ve Ekonomi Dergisi, 15(1): 141.

Sevencan, F., Uzun, N., Yücel, HE., Şener, A., Yılmaz, AE. ve Üner, S. (2011). Hacettepe Üniversitesi Tıp Fakültesi Dönem VI Öğrencilerinde Tükenmişlik Düzeyi ve Etkileyen Faktörler, Alındı ̆̆ 1 tarih: 12.03.2019, adres: http://www.hacettepetipdergisi.com/managete/fu_folder/201 1-01/html/2011-42-1-042-048.htm

Sürgevil Dalkılıç, O. (2014). Çalışma Hayatında Tükenmişlik Sendromu, Nobel Yayınevi, Ankara.

Şıklar, E. ve Tunalı, D. (2012). Çalışanların Tükenmişlik Düzeylerinin İncelenmesi: Eskişehir Örneği, Dumlupınar Üniversitesi Sosyal Bilimler Dergisi, (33): 77.

Tanner, B.M. (2007). Analysis of The Relationships Among Job Satisfaction, Organizational Trust, And Organizational Commitment in an Acute Care Hospital, Ph. D. Thesis, Faculty of Saybrook Graduate School and Research Center, San Francisco.

Üngüren, E., Doğan, H., Özmen, M. ve Tekin, Ö.A. (2010). Otel Çalışanlarının Tükenmişlik ve İş Tatmin Düzeyleri İlişkisi, Yaşar Üniversitesi Dergisi, 17(5): 2924.

Vnouckova, L. ve Klupakova, H. (2013). Impact of motivation principles on employee turnover. Central European Review of Economic Issues, (16): 80.

Yeğin, H.İ. (2014). Din Kültürü ve Ahlak Bilgisi Öğretmenlerinin Tükenmişlik Düzeyleri, EKEV Akademi Dergisi, 18(58): 317.

Yücel, İ. (2012). İş Tatmini ile Tükenmişlik Duygusu Arasındaki İlişki ve Algılanan Örgütsel Desteğin Bu İlişki Üzerindeki Etkisi: Sağlık Sektöründe Bir Uygulama. Akademik Bakış Dergisi, 33: 2-5. 